\title{
UK national laboratories face new threat of privatization
}

\begin{abstract}
London. Three years after being turned into 'executive agencies' and told to pay their way entirely through contracts with government departments and private industry, the five national laboratories run by Britain's Department of Trade and Industry (DTI) are once again under scrutiny.

Michael Heseltine, the president of the board of trade, has said that the laboratories must undergo a 'cultural change', with the
\end{abstract}

of the laboratory's 250 scientists will lose their jobs and the rest will be moved to the DTI-owned company AEA Technology at Harwell, itself scheduled for privatization.

The review is also likely to make little difference to the NEL in Glasgow, which provides testing facilities and other services for the engineering industry. The laboratory is scheduled for privatization in 1995 .

Officials at NEL say that a variety of new administrative procedures introduced since 1988, when

$\vec{a} \frac{\vec{a}}{z}$ the government tried unsuccessfully to privatize it, have already created the shift towards the industrial values being demanded by Heseltine. One important change is demanding greater accountability from individual projects.

But the privatization of NEL is still strongly opposed by the Institution of Professionals, Managers and Specialists, the trade union representing staff members. Union officials claim that the previous attempts to streamline the organization during its ef-

Acoustics research is one of many areas that NPL director Peter Clapham, right, has been forced to cut.

possibility of full-scale privatization, to bring themselves in line with the values and management practices of industry. With this in mind, he has asked outside consultants to study the future of five DTI laboratories: the National Physical Laboratory (NPL), the Laboratory of the Government Chemist and the National Weights and Measures Laboratory, all at Teddington outside London; the National Engineering Laboratory (NPL) in Glasgow and the Warren Spring Laboratory near Stevenage. In response, research staff complain that budget cuts and staff reductions have hindered their ability to provide long-term support to British industry.

The review appears to have come too late for Warren Spring, the government's main centre for environmental technology, which conducts work ranging from effluent measurement to industrial biosafety. Last week, Heseltine is reported to have told the director of the laboratory, Doug Cormack, that it would be closed down.

DTI says officially that it has made no firm decision about the future of the Warren Spring, and staff at the laboratory are still hoping that Heseltine can be persuaded to change his mind. If the decision stands, 150 the institute's industrial affiliates are worried that the cuts could jeopardize NPL's usefulness and its international credibility. According to Foxell, although some companies have criticized NPL for setting its fees too low and for at times spending too much time on projects that are no longer productive, they also feel that "NPL is carrying out important state-of-the-art work in fields such as optoelectronics which is vital to the success of companies working in the field".

Others claim that senior managers in industry and government have yet to realize the significance of the cuts because much of NPL's work is better known to technical staff. There is also concern that full-scale privatization could be counterproductive. "There is a danger that other countries, which provide strong government support to their measurement laboratories, will treat us as a joke," says Bill South, a non-executive director of Philips Electronics and a member of NPL's steering committee.

DTI officials are expected to respond to the criticism with a survey of industrialists. Laboratory officials and scientists hope that the results will influence the review being commissioned by Heseltine and prevent any hasty action that could inflict irreparable damage.

David Dickson

\section{US companies settle EPO patent suit}

Washington. Two leading US biotechnology companies, Amgen Inc. and Genetics Institute Inc., settled an old score last week with an agreement on damages in a six-year patent dispute involving erythropoietin (EPO), one of biotechnology's most lucrative drugs. It is used to treat anaemia by stimulating the body's own production of red blood cells. The settlement resolves all patent disputes over EPO in the United States between the two companies.

Under the settlement, Genetics Institute will pay Amgen US\$14 million in damages. In 1991, Genetics Institute took an \$11million charge against earnings after a federal appeals court upheld Amgen's EPO patent and ruled that Genetics Institute's patent was invalid (see Nature 350, 99; 1991). Licensee Boehringer Mannheim $\mathrm{GmbH}$ has also agreed to reimburse Genetics Institute for a portion of the costs. Sales of Amgen's EPO product, approved in the United States in 1989, reached $\$ 507$ million in 1992 .

In a separate patent settlement, Baxter International, Genetic Institute's worldwide licensee for its recombinant Factor VIII product (Recombinate AHF), has agreed to pay $\$ 105$ million to Rhône-Poulenc Rorer and the Scripps Research Institute of $\mathrm{La}$ Jolla, California. Genetics Institute will share the cost of future royalties paid to RhônePoulenc Rorer on Baxter's sales of Recombinate AHF, a drug used to treat haemophilia A.

Diane Gershon 